\title{
The Impact of Automation on Job Requirements and Qualifications for Catalogers and Reference Librarians in Academic Libraries
}

\section{Hong Xu}

The purpose of this study is to trace the impact of automation on job requirements and qualifications of catalogers and reference librarians in academic libraries by comparing and analyzing job advertisements from 1971 to 1990. Four periods were identified to reflect the influence of each important library automation development on job descriptions. Chi-square tests were used to see whether there are significant differences between catalog librarians and reference librarians with regard to duties and qualifications in each period; and whether there are significant differences in professional duties and qualifications for catalog librarians and reference librarians over the periods. With the development of automation in libraries, the requirements of previous work experiences for catalogers and reference librarians have become more similar, increasing needs for computer skills can be found in both groups, and a shortage of catalogers and greater demand for reference librarians have led to more entry-level positions being posted in both groups. There still remain differences between catalogers and reference librarians in major responsibilities and knowledge or skills needed.

\footnotetext{
$\mathbf{W}$

hile the cataloging unit of a library has traditionally been responsible for describing and classifying the library's holdings, thus providing bibliographic access to the collections, the reference unit has been more concerned with the retrieval and transfer of information required by the library user. It is sometimes said that catalogers "like to work with books" while
}

reference librarians "like to work with people." Because of this basic split, the two specialties have tended to become more isolated than integrated over the years, although Miller once noted that "the catalog and reference departments have been called the 'Siamese twins' of library work" (1931, p. 169).

Since the 1970s, as more and more

Honc Xu is a Ph.D. candidate at the Graduate School of Library and Information Science, University of Illinois at Urbana-Champaign (hongxu@alexia.lis.uiuc.edu). The critical and very valuable comments of Professor Brett Sutton are gratefully acknowledged. Professor F. W. Lancaster guided and encouraged me throughout this research. Manuscript received April 29, 1995; revised August 21, 1995; accepted for publication September 11, 1995. 
technological innovations have been introduced in libraries, more and more members of the library staff have been required to participate in library automation activities. For example, catalogers and reference librarians have been involved in designing, organizing, and using online catalogs. With the implementation of user-friendly online catalogs and the availability of information in CD-ROM format, the roles of reference librarians and catalogers have been changing. Most recently, the development of the Internet, which offers new methods of delivering information to researchers, presents new opportunities and challenges for academic librarians.

There is a general agreement that bibliographic utilities and computer databases have allowed duties once performed by professional catalogers and reference librarians (such as copy cataloging and ready reference) to be executed at a lower organizational level. The new technology has also led to an increasing need for catalogers and reference librarians to have both computer skills and administrative experience.

An analysis of job descriptions for catalogers and reference librarians over several years might indicate the pace of library automation. Job advertisements reflect current priorities and the desires of employers at certain times under certain social conditions. A typical advertisement describes the position and enumerates the required qualifications. Some notices also include preferred or desirable requirements. Therefore, such advertisements might be an indicator of changing duties and responsibilities in the profession.

However, there is a time gap from the implementation of new technology in libraries to the corresponding changes in library professional duties and responsibilities. "Cultural lag," as proposed by American sociologist William Ogburn in his influential book Social Change with Respect to Culture and Original Nature (1922), might be the major reason. Ogburn stated that normative and social relationship changes cannot occur instantaneously to keep pace with technological innovations; in fact they might change very slowly. Because technological change results from new combinations of existing technology, the larger the technical knowledge-base of society, the greater the possibility for new combinations, or technological innovations. Therefore technological change (material cultural change) tends to grow exponentially. Nonmaterial culture adapts to material culture, which means that methods, processes, and organizational structures for using and controlling new technology are developed after the acceptance of any new technique. In librarianship, budget limitations and the limited human capacity to absorb and adapt to change (Shreeves 1994) further frustrate the timely evolution of requirements and duties of professionals.

One might find, for instance, that end user online searching and the introduction of CD-ROM systems in academic libraries during the 1980s not only changed user expectations for reference services but also changed the way reference librarians perform their jobs. However, requirements concerning the knowledge of such relevant skills did not immediately appear in job advertisements. Similarly, the advent of the Internet in the 1990s will certainly challenge academic library services and other aspects of librarians' roles. However, because "there is a fundamental difference in the nature of the networked information retrieval tools and the automated systems that have been designed for library use" (Summerhill 1994, 143), reference services for Internet resources have not yet been provided by academic libraries, leading one to expect that job advertisements would not yet show the influence of the Internet.

This study, then, is an attempt to trace the impact of automation on the job requirements and qualifications of catalogers and reference librarians in academic libraries by comparing and analyzing job advertisements from 1971 to 1990.

\section{BACKGROUND}

Many writers have described and predicted the shifts in library organizational structure, personnel duties, collection de- 
velopment expenditures, and user expectations for library services (Nofsinger and Bosch 1994) that have been brought about by automation. A lively discussion of the impact of automation on cataloging and reference work in academic libraries has appeared in library literature since the 1970s, and can be described under three subheadings: (1) impact on catalog librarians; (2) impact on reference librarians; and (3) the relationship between catalog and reference librarians in a continuously changing environment.

\section{IMPACT ON CATALOG LIBRARIANS}

Cataloging departments began to employ bibliographic utilities such as the OCLC Online Computer Library Center, Inc., to process materials during the early 1970s. Automation of cataloging has had a major impact on technical services staff and jobs. There is a general perception that "original" cataloging departments have shrunk; thus automation has brought about a change in both staff size and composition.

The earliest studies on the impact of bibliographic utilities date from the mid1970s. Hewitt $(1976,274)$ found that $63 \%$ of the 47 charter OCLC member libraries had reduced cataloging staff, with a total of 76.83 net positions dropped. He concluded that "the majority of libraries adequately staffed prior to use of the system should find it possible to decrease the size of cataloging [departments]."

Since their introduction in the 1970s, bibliographic utilities such as OCLC and the Research Libraries Information Network (RLIN) have played a major role in providing various kinds of automated support for the processing activities required by libraries. Spyers-Duran $(1979,35)$ showed that, in many libraries, $80 \%$ to $90 \%$ of all cataloging was performed by nonprofessional staff with the aid of automation. An obvious conclusion was that shared cataloging had reduced the need for professional cataloging in a given library.

In many research libraries, there is now much less original cataloging activity taking place. For example, Mandel (1992) showed that only $20 \%$ of the total catalog- ing output of an Association of Research Libraries (ARL) member university library in 1989 was original cataloging.

However, Hill (1985) and Callahan and MacLeod (1994) both pointed out that pessimistic writings and negative attitudes on the future of cataloging and other factors conveyed the impression that cataloging was an unattractive occupation and that this created a major problem in finding well-qualified catalogers. By 1985 there was a cataloger crisis, which led to the formation of a task force within the Cataloging and Classification Section (CCS) of the Association for Library Collections and Technical Services (ALCTS). After surveying 83 institutions that had advertised 94 positions with cataloging components, the task force found that $64 \%$ had reposted positions; $51 \%$ reported a disappointing applicant pool; and $77 \%$ considered recruitment of catalogers more difficult than it had been three to four years earlier. The cataloger crisis brought about a decline in the quality of catalogers by increasing the number of cataloging positions filled as entry-level positions (Sanders 1986). According to Hoerman (1990), the short supply of catalogers still exists.

The shift from original cataloging to copy cataloging might reduce the need for original catalogers, but new responsibilities for catalogers can also emerge. With the increasing use of local integrated library systems for cataloging, authority control, and online catalogs, there is a need for database maintenance routines within a catalog department. The implementation of online catalogs in libraries requires that catalogers work closely with systems and public service librarians to determine specifications for the cataloging and authority subsystems and the online catalog. The demand for expertise and knowledge of how to organize, retrieve, and display information has grown (Eaton 1989, 331). McCombs (1986) predicted that the cataloger of the future is more likely to be a database manager, with varying responsibilities within the library's bibliographic control system. In addition to the traditional cataloging knowledge, staff training, and supervisory skills cata- 
logers need, they will also need knowledge of planning, designing, coordinating, and systems analysis and relevant computer applications (Hill 1988, 97-98; Bishoff 1989, 41-42).

\section{IMPACT ON REFERENCE LIBRARIANS}

One of the most critical trends in libraries has been the shift from the library-centered organization (with public, technical, and administration services as the basic structural divisions) to organizational structures based upon client-centered divisions aimed at language, subject, or audience groups (Intner 1991). This change implies an increasing demand for reference librarians because reference service has become a major and essential part of public service. Traditionally, circulation and interlibrary loan also belonged to public service, but computer and telecommunication technologies have brought those two activities into the area of more technically oriented services performed by paraprofessionals. On the other hand, every time that the library increases accessibility to information, new constituencies are created along with new demands for public service staffing (Atkinson 1984; Williams 1991).

The first significant move toward automation in reference service can be traced to the introduction of online searching of commercial databases through vendors like DIALOG and BRS. In academic reference work, widespread use occurred in the late 1970s and early 1980s. Most academic reference librarians have been accessing bibliographic databases via OCLC, DIALOG, and BRS for a period of about twenty years. Other databases that were developed later (for example, on CD-ROM) offer different information and require different use protocols or have unique features that must be understood to maximize effective use. Moreover, new databases are emerging each month. Hallman (1990) and Crane (1990) have pointed out that, as a result, reference librarians now need a thorough understanding of electronic information technology.
Constant change in technologies also means that demand for instruction in the use of library resources and services will continue to grow (Lewis 1994, 448). The implementation of user-friendly online catalogs in the early 1980 s brought about an increased need for user training and support. The real breakthrough in end user searching came in the mid-1980s with the introduction of optical disc technology into the searching environmentCD-ROM searching. In 1988 OCLC surveyed its participating members and found that seven out of eight academic libraries $(84 \%)$ had at least one CD-ROM product (Morrison 1990). Reese (1990) pointed out that implementing CD-ROM meant a change in the focus of reference service. Many libraries have made end user instruction an integral part of library services.

With the increasing use of optical disc and other new technologies, a major role of the reference librarian is as teacher, consultant, and organizer (Boss 1987; Reese 1990; Faries 1994). Because answering routine reference questions and other traditional work will often be done by paraprofessionals, reference work will require more than traditional directional and informational assistance. Reference librarians not only have to learn the new printed reference sources, they must also become technological experts in order to stay on top of the constantly changing developments in the field (Huang 1990). Crane (1990) pointed out that reference librarians should have strong backgrounds in information resource management as well as broad general academic credentials. Lewis (1994) stated that subject expertise and liaison with a wide range of clients will become the unifying thread of reference work.

\section{The Relationship Between Catalog and REFERENCE LibraRians}

With the involvement of new technologies in reference services as well as in cataloging, the assimilation of reference and catalog librarians was highlighted. 
Arret (1979) was among the first to emphasize the importance of integrating cataloging and reference services. He suggested the need for a flexible and integrated staffing pattern to match the capabilities of an automation system. If reference librarians cannot understand the tools of catalogers (e.g., Anglo-American Cataloguing Rules, second edition [AACR2], Machine-Readable Cataloging [MARC], or Library of Congress Subject Headings [LCSH]) or if catalogers do not understand the "real-world" requests and problems of users, then the online catalog cannot serve users effectively (Walbridge 1991). McCombs (1986), Cochrane (1983), and Futas (1988) all suggested that reference librarians should take part in online catalog design and improvement. Neal (1989) stated that catalog librarians involved in reference services can provide effective public service because of their knowledge of bibliographic utilities. Eaton (1989) believes that the implementation of online catalogs in libraries requires that catalogers work closely with systems librarians and public service librarians to determine specifications between the cataloging and authority subsystems and the online catalog because cataloging practice has repercussions in online catalog displays.

With libraries changing from librarycentered organizations to client-centered divisions, and with the change in attitude from ownership to access, the distinction between technical services and public services is blurring (McCombs 1986) and a new kind of librarian-the holistic librarian-is evolving, with the roles of cataloging and reference services merged.

According to Gorman (1983), the term "holistic librarian" refers to librarians who will carry out the whole range of professional duties, including selection and collection development, reference service, original cataloging, and bibliographic services. The holistic model provides the opportunity to increase the number of librarians who work directly with patrons (Clark and Bingham 1989). Although truly holistic librarians might not be suitable for all kinds of academic libraries, this idea typifies the integration of catalog and reference librarians.

\section{METHODOLOGY}

Several studies based on job advertisements have been conducted in recent years. The major purpose or focus of these, however, has been an analysis of the job market and predictions of possible recruitment trends in the library and information field.

Block (1980) conducted an academic library job market study using a positions announcement file maintained by the Graduate School of Library and Information Science of the University of Texas at Austin. Block examined the characteristics of library positions based upon advertised requirements, providing some data relevant to making career decisions, to hiring, and to designing curricula. Block found that the academic library job market was dominated by rather traditional personnel functions and position offerings (with cataloging and reference comprising nearly half of the total).

In another academic library job content analysis, Reser and Schuneman (1992) compared public and technical services, with regard to computer skills, foreign-language requirements, previous work experience, educational requirements, and minimum salary offered to reflect the situation of the job market in 1988. They concluded that technical services position advertisements required more computer skills and previous work experience and were more than twice as likely to require foreign-language skills. Public services candidates, on the other hand, were expected to have more advanced degrees. It should be noted, however, that one can obtain only limited data from this study because very rough categories were used (e.g., computer skills were divided into "not stated," "preferred," and "required") and because advertisements for only one year were analyzed.

The impact of automation on professional catalogers in different types of libraries was examined by Furuta (1990), 
who analyzed job advertisements from 1970 to 1989. Based on pure descriptive statistics about the number of catalogers posted each year, the percentage of jobs requiring automation, nonadministrative jobs with supervisory responsibilities, and nonadministrative jobs with noncataloging duties, Furuta reached the following conclusions: the data neither supported nor rejected the assertion that automation had reduced the need for catalogers; the majority of advertisements mentioned automation; the future of professional catalogers might not lie in an administrative role; and the "holistic" librarian might not constitute a trend in libraries. Because the data the author chose to present represented different types of libraries, and because only descriptive statistics were used, the conclusions might not be accurate for academic libraries.

The data used in the present study were drawn from American Libraries. This journal was chosen because it has a wide circulation and appears to be the traditional place to advertise academic library job openings. Job advertisements about catalogers and reference librarians in academic libraries from 1971 to 1990 were the raw material for analysis. This range of years was selected in order to account for the impact of bibliographic utilities in cataloging departments, as well as the impact of the CD-ROM end user searching service on reference departments.

A random sample of forty issues (two random issues per year) was drawn from 1971 to 1990. Due to seasonal fluctuations, certain issues had more job postings and other issues had fewer. However, this should not have affected the statistical results of the study because random sampling should maximize the information obtained or minimize the bound on the error of estimation (Scheaffer et al. 1986, 79-80). Only full-time positions were recorded, including temporary positions if the contract period was at least nine months. The type of job could sometimes be discerned by its title (catalog librarian, assistant reference librarian, for example), but when the title was vague a type was identified by examining the responsibilities or duties listed.
The sample was stratified by dividing it into four periods in order to trace the influence of each important library automation development on job requirements: 1971-1975, 1976-1980, 19811985, 1986-1990. The periods chosen were evenly spaced to reflect fluctuations in the job market and to indicate when certain changes began to appear. Extensive use of OCLC from the mid-1970s might have been the first indicator to distinguish traditional cataloging activity from computer-supported bibliographic activity; online catalogs from the beginning of the 1980s might have been another important movement to bring about changes in technical and public services; and, then, CD-ROM has had a major impact on library services since 1985 . The following components (or variables) were grouped: subject knowledge in other academic disciplines, work experience, computer skills, administrative responsibilities, and other skills. After all of the data were accumulated, they were coded so that the Statistical Analysis System (SAS) could be used to analyze the coded data and to provide the descriptive and inferential statistics.

Based on previous studies on catalogers and reference librarians and on the contents of advertisements, the following specific research questions were formulated:

1. Are there any significant differences between catalog librarians and reference librarians with regard to subject knowledge, work experience, computer skills, administrative responsibilities, and other skills in each period?

2. Are there any significant differences in subject knowledge, work experience, computer skills, administrative responsibilities, and other skills for catalog or reference librarians over the periods?

Accordingly, two major hypotheses were to be tested:

1. There are significant differences between catalog librarians and reference librarians with regard to duties (responsibilities) and qualifications (or requirements) in each period. 
2. There are significant differences in professional duties (or responsibilities) and qualifications (or requirements) for catalog or reference librarians over the periods.

\section{RESUltS AND ANALYSIS}

The number of positions for catalog and reference librarians over the twenty years and the number of listings that asked for different requirements and responsibilities are shown in tables 1 and 2. As can be seen, 574 postings were announced in forty issues. The overall demand for reference librarians was slightly higher than that for catalogers (over $54 \%$ of the total postings were for reference). The number of postings for catalog librarians was somewhat higher than the number for reference librarians in the first period, but after 1976 the demand for the latter jumped from five in 1976 to twenty-five in 1980. Since 1988 the demand for reference librarians has been steady, while the demand for catalogers has continued to rise. However, the absolute number is still lower than that for reference librarians.

While the wide implementation of OCLC and, later, RLIN and other utilities might have caused a temporary surplus of catalogers, online catalogs have created the need for cooperation between catalogers and reference librarians. Thus the number of cataloger postings increased immediately after 1981. The application of CD-ROM, on the other hand, might create an increasing demand for reference librarians.

According to Bishoff (1989, 40-42), there were dramatic increases in the number of libraries during the mid-1970s, which resulted in an increasing need for catalogers. By 1975, because of economic and technical factors, libraries required fewer catalogers. The adoption of bibliographic services such as OCLC, WLN, and RLIN, together with the influence of economic factors, reduced the demand for professional catalog librarians. This might not be consistent with the present findings but, as Furuta (1990) pointed out, the relative lack of advertisements during the 1970s makes it difficult to track the real picture at that time. The example given by Furuta shows that there were 3,467 known placements for all kinds of libraries, of which 2,344 were professional positions. However, the data from her study result in only 102 nonadministrative postings. It is obvious that there were many more vacant positions in the 1970s than the data would suggest (Furuta 1990, 245).

The Library Statistics for Colleges and Universities by the National Center for Educational Statistics (NCES) from $1970-71$ to $1987-88$ show that the number of librarians increased very slightly over the years, remaining relatively steady until 1984-85, when there was a large drop in the total number of librarians followed by a great upward trend in 198788. Cooper $(1984,345)$ claims that replacement demand, which is the number of jobs that will be created as a result of individuals retiring or leaving their present positions, is the dominant source of new jobs, while expansion demand, which is the number of jobs created as a result of growth in the field, is a small fraction of the total. If automation leads to the reduction of cataloging positions, a large proportion of the postings for catalogers would be for replacement rather than expansion purposes. More expansion positions might occur in reference and other public services. The data collected here do not show the recruitment type. However, based on the sample data, there seem to be slightly fewer cataloging positions advertised than reference positions. There has been an increase in both, although the functions and responsibilities of each job might have changed with the development of automation in academic libraries. This trend is reflected more clearly in figures 1 and 2.

\section{SUBJECT KNOWLEDGE IN OTHER ACADEMIC Disciplines}

Since the Association of College and Research Libraries' (ACRL) board of directors set it as the basic educational requirement for academic librarians, the American Library Association-accredited Master of Library Science (M.L.S.) has gradually become the universal standard 


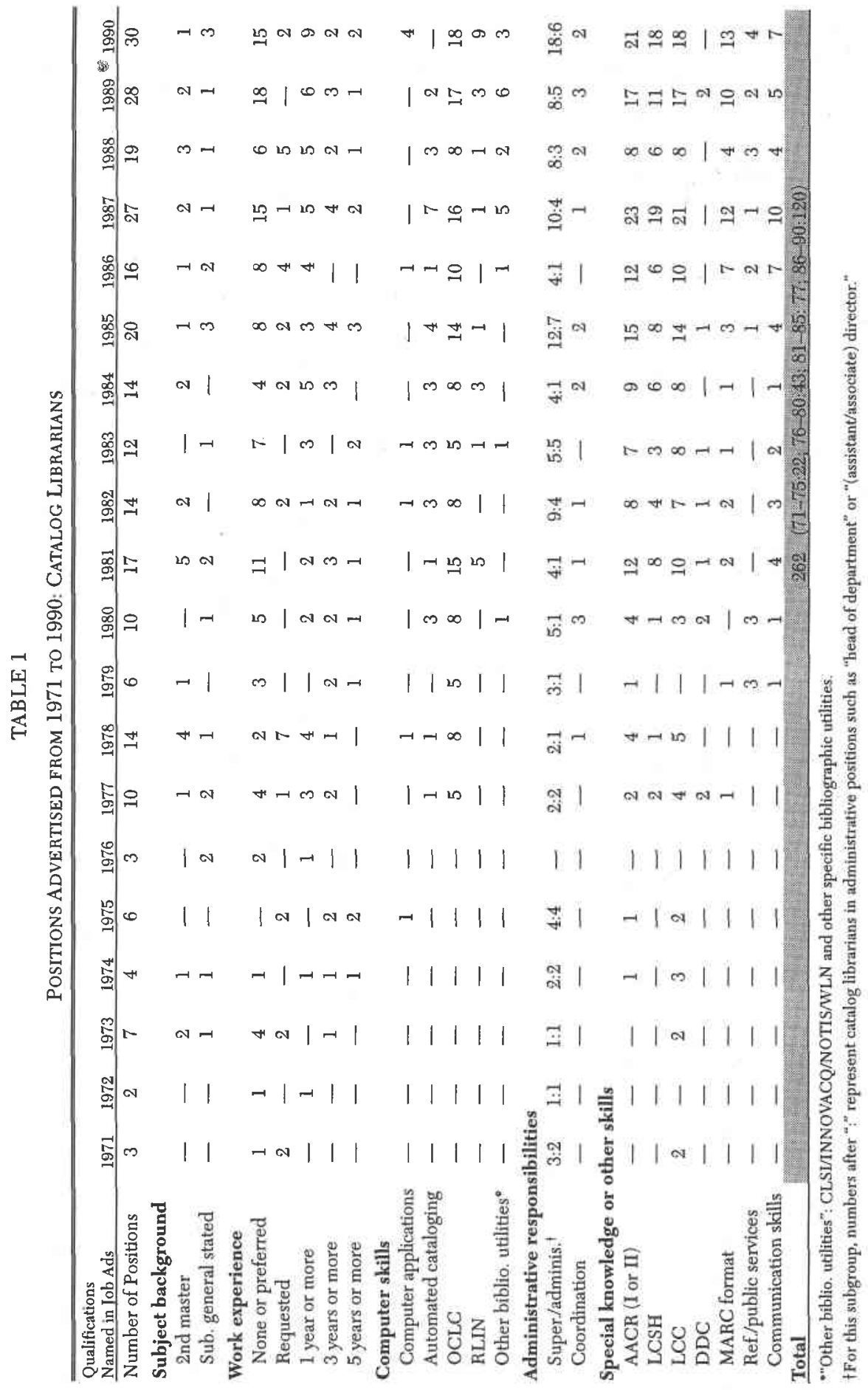




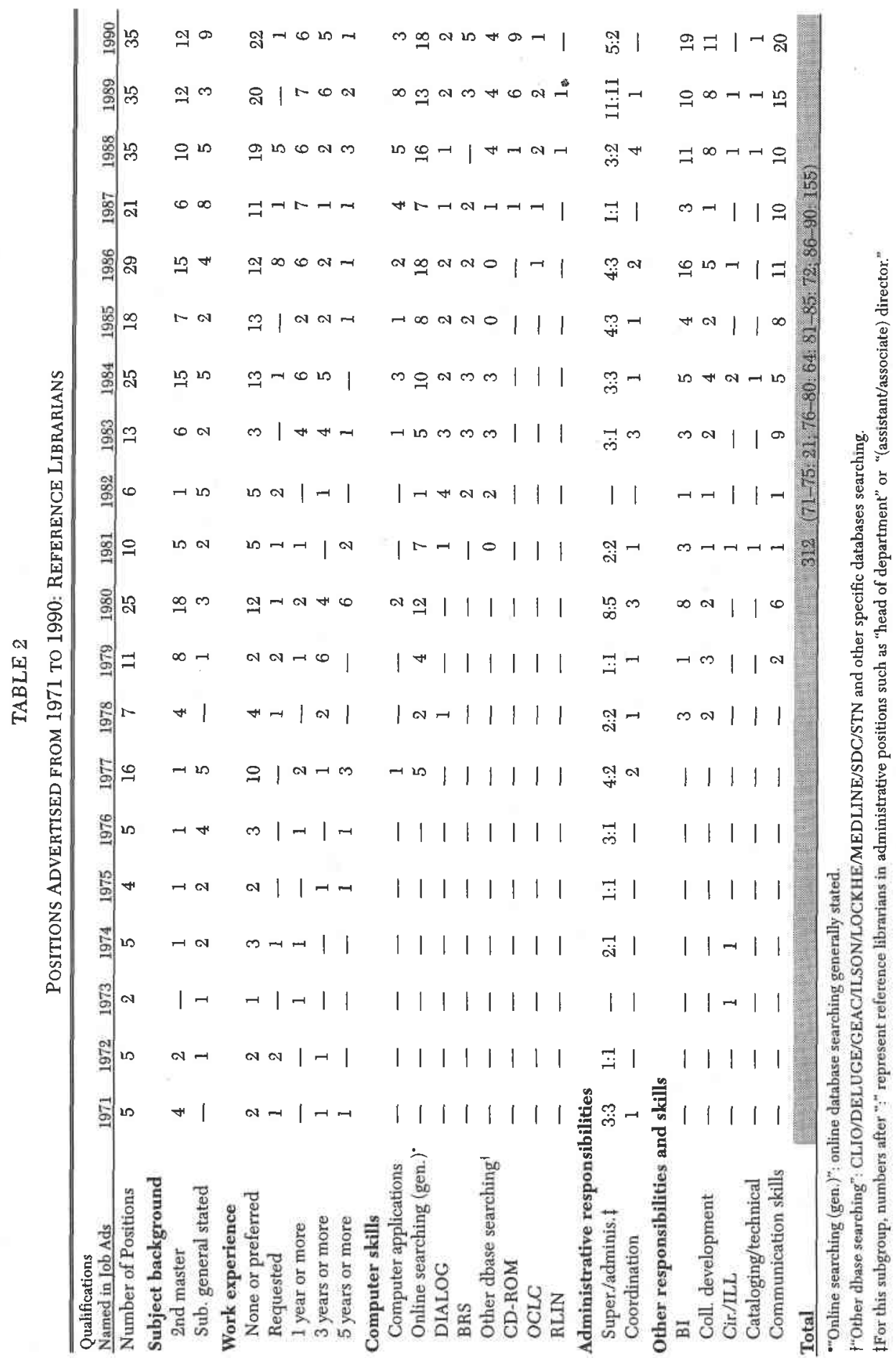




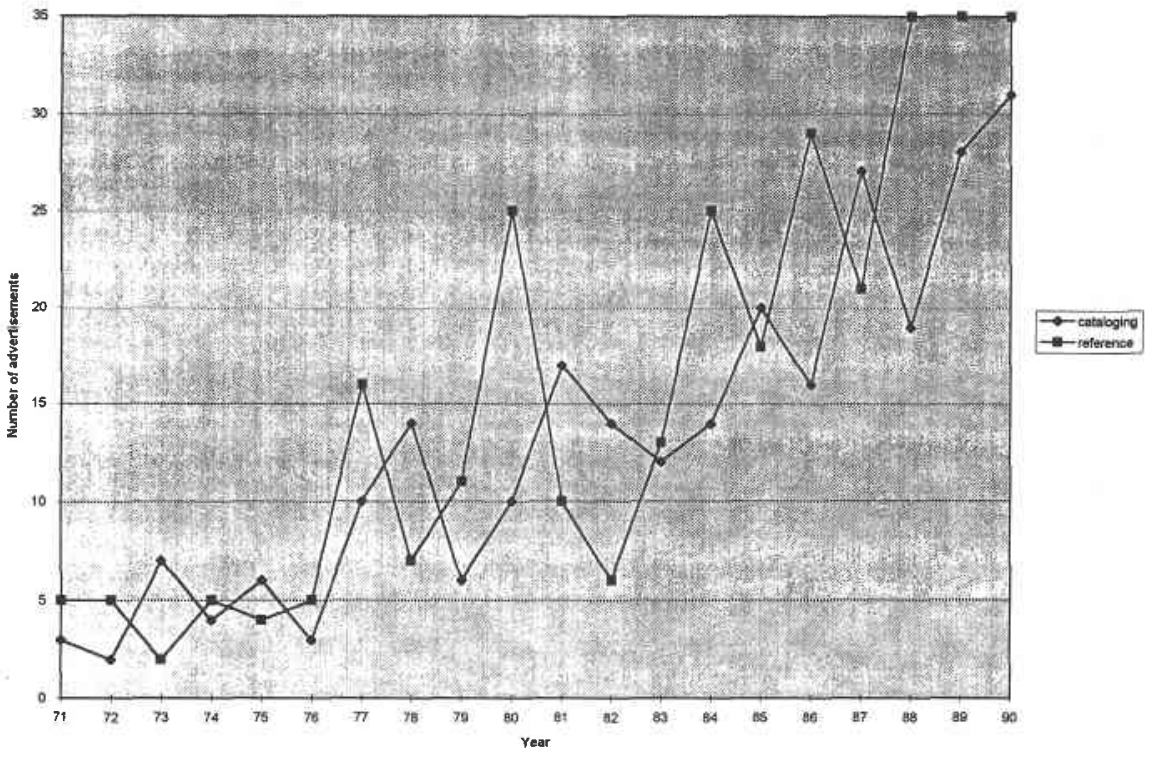

Figure 1. Number of catalog and reference librarians advertised (1971-90)

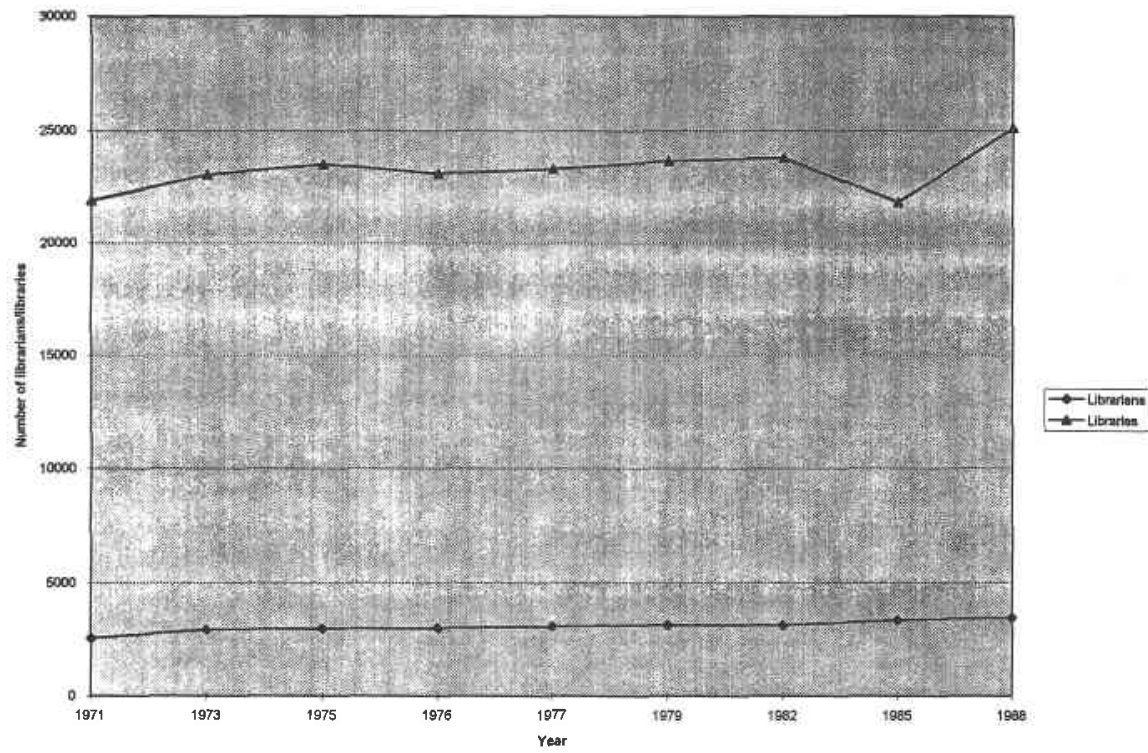

Figure 2. Statistics of academic libraries (1970/71-87/88)

requirement for librarian positions. Therefore, it is not useful to analyze the professional education requirements for catalog and reference librarians. However, subject background knowledge was considered an important element to use to compare the requirements for catalog and reference librarians. Subject background knowledge was grouped into the following categories: second masters de- 
gree required; general background knowledge stated (such as subject background knowledge or bachelors degree in a subject field); and no subject background needed (or none mentioned).

From the advertisements, it is evident that many more reference services positions include a component of book selection or collection development in a specific subject area. Statistically significant differences between catalog and reference librarians in the first period (at $p$ level) and in the other three periods (at $p$ level) were found when considering requirement or preference for subject background (see tables 3A-3D). Over half of the reference positions required subject specializations, whereas very few cata- loger postings asked for subject background. During the 1971-1975 period, nearly $67 \%$ of positions for reference librarians required or preferred subject knowledge, but only $23 \%$ of cataloging positions did; in the second period, the figures are $70 \%$ for reference and $27 \%$ for cataloging. Since that period, however, there has been a trend to decrease the requirement of subject background for both: $69 \%$ in the third period and $54 \%$ in the fourth period for reference librarians, and $20 \%$ in the third period and $14 \%$ in the fourth period for catalog librarians, although no statistically significant differences were found within either group over the four periods (see tables $4 A-4 B$ ). Increasing demand for reference librarians

TABLE 3A

SUBJECT BACKGROUND REQUIRED DURING 1971-75

\begin{tabular}{lrrrrrrrr}
\hline \hline & \multicolumn{2}{c}{ 2nd Master } & \multicolumn{2}{c}{ General Stated } & \multicolumn{2}{c}{ Not Mentioned } & \multicolumn{2}{c}{ Total } \\
Type & \multicolumn{1}{c}{ No. } & \multicolumn{1}{c}{$\%$} & \multicolumn{1}{c}{ No. } & \multicolumn{1}{c}{$\%$} & \multicolumn{1}{c}{ No. } & \multicolumn{1}{c}{$\%$} & \multicolumn{1}{c}{ No. } & \multicolumn{1}{c}{$\%$} \\
\hline Catalog librarians & 3 & 13.64 & 2 & 9.09 & 17 & 77.27 & 22 & 51.16 \\
Reference librarians & 8 & 38.10 & 6 & 28.57 & 7 & 33.33 & 21 & 48.84 \\
Total & 11 & 25.58 & 8 & 18.60 & 24 & 55.81 & 43 & 100.00 \\
\hline
\end{tabular}

$X^{2}=8.421, d f=2, p=0.015$

TABLE 3B

SUBJECT BACKGROUND REQUIRED DURING 1976-80

\begin{tabular}{lrrrrrrrr}
\hline \hline & \multicolumn{2}{c}{ 2nd Master } & \multicolumn{2}{c}{ General Stated } & \multicolumn{2}{c}{ Not Mentioned } & \multicolumn{2}{c}{ Total } \\
Type & No. & $\%$ & \multicolumn{1}{c}{ No. } & \multicolumn{1}{c}{$\%$} & No. & $\%$ & \multicolumn{1}{c}{ No. } & \multicolumn{1}{c}{$\%$} \\
\hline Catalog librarians & 6 & 13.95 & 6 & 13.95 & 31 & 72.09 & 43 & 40.19 \\
Reference librarians & 32 & 50.00 & 13 & 20.31 & 19 & 29.69 & 64 & 59.81 \\
Total & 38 & 35.51 & 19 & 17.76 & 50 & 46.73 & 107 & 100.00 \\
\hline
\end{tabular}

$X^{2}=19.893, d f=2, p=0.000$

TABLE 3C

SUBJECT BACKGROUND REQUIRED DURING 1981-85

\begin{tabular}{lcccccccc}
\hline & \multicolumn{2}{c}{ 2nd Master } & \multicolumn{2}{c}{ General Stated } & \multicolumn{2}{c}{ Not Mentioned } & \multicolumn{2}{c}{ Total } \\
Type & No & $\%$ & \multicolumn{1}{c}{ No } & \multicolumn{1}{c}{$\%$} & No. & $\%$ & \multicolumn{1}{c}{ No. } & \multicolumn{1}{c}{$\%$} \\
\hline Catalog librarians & 10 & 12.99 & 6 & 7.79 & 61 & 79.22 & 77 & 51.68 \\
Reference librarians & 34 & 47.22 & 16 & 22.22 & 22 & 30.56 & 72 & 48.32 \\
Total & 44 & 29.53 & 22 & 14.77 & 83 & 55.70 & 149 & 100.00 \\
\hline
\end{tabular}

$X^{2}=35.834, d f=2, p=0.000$ 
TABLE 3D

SUbJECT BACKgRound REQUIRED DURING 1986-90

\begin{tabular}{lrrrrrrrr}
\hline & \multicolumn{2}{c}{ 2nd Master } & \multicolumn{3}{c}{ General Stated } & \multicolumn{2}{c}{ Not Mentioned } & \multicolumn{2}{c}{ Total } \\
Type & \multicolumn{1}{c}{ No. } & \multicolumn{1}{c}{$\%$} & \multicolumn{1}{c}{ No. } & \multicolumn{1}{c}{$\%$} & \multicolumn{1}{c}{ No. } & $\%$ & \multicolumn{1}{c}{ No. } & $\%$ \\
\hline Catalog librarians & 9 & 7.50 & 8 & 6.67 & 103 & 85.83 & 120 & 43.64 \\
Reference librarians & 55 & 35.48 & 29 & 18.71 & 71 & 45.81 & 155 & 56.36 \\
Total & 64 & 23.27 & 37 & 13.45 & 174 & 63.27 & 275 & 100.00 \\
\hline
\end{tabular}

$X^{2}=47.176, d f=2, p=0,000$

and the shortage of catalogers, which brought about more entry-level position openings, might be the major reason.

\section{WORK EXPERIENCE}

Each advertisement was analyzed to determine whether previous work experience was needed or preferred. Five levels were identified according to the contents of the advertisements: not stated or preferred or desired; work experience required; at least one year or more; at least three years or more; at least five years or more. Because some of the descriptions specified the type of experience required or preferred (e.g., with management experience) and some did not, no attempt was made to distinguish the type of experience when coding for this study.

Although there were no significant differences within either group over the various periods with regard to work experience (tables $5 \mathrm{~A}-5 \mathrm{~B}$ ), cataloging positions with work experience "not stated or preferred or desired" increased from about

\section{TABLE 4A}

Subject Background Required for Catalog librarians over four Periods

\begin{tabular}{lrrrrrrrrrr}
\hline \hline & \multicolumn{2}{c}{$1971-75$} & \multicolumn{2}{c}{$1976-80$} & \multicolumn{2}{c}{$1981-85$} & \multicolumn{1}{c}{$1986-90$} & \multicolumn{2}{c}{ Total } \\
Subject & No. & \multicolumn{1}{c}{$\%$} & \multicolumn{1}{c}{ No. } & \multicolumn{1}{c}{$\%$} & \multicolumn{1}{c}{ No. } & \multicolumn{1}{c}{$\%$} & No. & $\%$ & \multicolumn{1}{c}{ No. } & \multicolumn{1}{c}{$\%$} \\
\hline 2nd master & 3 & 13.64 & 6 & 13.95 & 10 & 12.99 & 9 & 7.50 & 28 & 10.69 \\
General stated & 2 & 9.09 & 6 & 13.95 & 7 & 7.79 & 8 & 6.67 & 22 & 8.40 \\
Not mentioned & 17 & 77.27 & 31 & 72.09 & 61 & 79.22 & 103 & 85.83 & 212 & 80.92 \\
Total & 22 & 8.40 & 43 & 16.41 & 77 & 29.39 & 120 & 45.80 & 262 & 100.00 \\
\hline
\end{tabular}

$X^{2}=5.021, d f=6, p=0.541$

\section{TABLE 4B}

Subject Background ReQuired for Reference Librarians over Four Periods

\begin{tabular}{lrrrrrrrrrrr}
\hline & \multicolumn{2}{c}{$1971-75$} & \multicolumn{2}{c}{$1976-80$} & \multicolumn{2}{c}{$1981-85$} & \multicolumn{2}{c}{$1986-90$} & \multicolumn{2}{c}{ Total } \\
Subject & No. & $\%$ & \multicolumn{1}{c}{ No. } & $\%$ & No. & $\%$ & \multicolumn{1}{c}{ No. } & $\%$ & \multicolumn{1}{c}{ No. } & $\%$ \\
\hline 2nd master & 8 & 38.10 & 32 & 50.00 & 34 & 47.22 & 55 & 25.48 & 129 & 41.35 \\
General stated & 6 & 28.57 & 13 & 20.31 & 16 & 22.22 & 29 & 18.71 & 64 & 20.51 \\
Not mentioned & 7 & 33.33 & 19 & 29.69 & 22 & 30.56 & 71 & 45.81 & 119 & 38.14 \\
Total & 21 & 6.73 & 64 & 20.51 & 72 & 23.08 & 155 & 49.68 & 312 & 100.00 \\
\hline
\end{tabular}

$X^{2}=8.917, d f=6, p=0.178$ 
TABLE 5A

Work Experience Required for Catalog Librarians over Four Periods

\begin{tabular}{lrrrrrrrrrr}
\hline \hline & \multicolumn{2}{c}{$1971-75$} & \multicolumn{2}{c}{$1976-80$} & \multicolumn{2}{c}{$1981-85$} & \multicolumn{2}{c}{$1986-90$} & \multicolumn{2}{c}{ Total } \\
Work Experience & \multicolumn{1}{c}{ No. } & \multicolumn{1}{c}{$\%$} & \multicolumn{1}{c}{ No. } & $\%$ & \multicolumn{1}{c}{ No } & $\%$ & \multicolumn{1}{c}{ No. } & $\%$ & \multicolumn{1}{c}{ No. } & $\%$ \\
\hline $\begin{array}{l}\text { Not stated/ } \\
\text { prefer }\end{array}$ & 7 & 31.82 & 16 & 37.21 & 38 & 49.35 & 62 & 51.67 & 123 & 46.95 \\
Required & 6 & 27.27 & 8 & 18.60 & 6 & 7.79 & 12 & 10.00 & 32 & 12.21 \\
1 year or more & 2 & 9.09 & 10 & 23.26 & 14 & 18.18 & 29 & 24.17 & 55 & 20.99 \\
3 years or more & 4 & 18.18 & 7 & 16.28 & 12 & 15.58 & 11 & 9.17 & 34 & 12.98 \\
5 years or more & 3 & 13.64 & 2 & 4.65 & 7 & 9.09 & 6 & 5.00 & 218 & 6.87 \\
Total & 22 & 8.40 & 43 & 16.41 & 77 & 29.39 & 120 & 45.80 & 262 & 100.00 \\
\hline
\end{tabular}

$X^{2}=17.801, d f=12, p=0.122$

TABLE 5B

Work Experience Required for Reference Librarians over Four Periods

\begin{tabular}{lrrrrrrrrrr}
\hline \hline & \multicolumn{2}{c}{$1971-75$} & \multicolumn{2}{c}{$1976-80$} & \multicolumn{2}{c}{$1981-85$} & \multicolumn{2}{c}{$1986-90$} & \multicolumn{2}{c}{ Total } \\
Work Experience & \multicolumn{1}{c}{ No. } & \multicolumn{1}{c}{$\%$} & \multicolumn{1}{c}{ No } & \multicolumn{1}{c}{$\%$} & \multicolumn{1}{c}{ No. } & \multicolumn{1}{c}{$\%$} & \multicolumn{1}{c}{ No. } & \multicolumn{1}{c}{$\%$} & \multicolumn{1}{c}{ No. } & $\%$ \\
\hline Not stated & & & & & & & & & & \\
$\quad$ prefer & 10 & 47.62 & 31 & 48.44 & 39 & 54.17 & 84 & 54.19 & 164 & 52.56 \\
Required & 4 & 19.05 & 4 & 6.25 & 4 & 5.56 & 15 & 9.68 & 27 & 8.65 \\
1 year or more & 2 & 9.52 & 6 & 9.38 & 13 & 18.06 & 32 & 20.65 & 53 & 16.99 \\
3 years or more & 3 & 14.29 & 13 & 20.31 & 12 & 16.67 & 16 & 10.32 & 44 & 14.10 \\
5 years or more & 2 & 9.52 & 10 & 15.63 & 4 & 5.56 & 8 & 5.16 & 24 & 7.69 \\
Total & 21 & 6.73 & 64 & 20.51 & 72 & 23.08 & 155 & 49.68 & 312 & 100.00 \\
\hline
\end{tabular}

$X^{2}=19.297, d f=12, p=0.082$

$32 \%$ in the first period to $52 \%$ in the fourth period; the comparable increase for reference positions was $48 \%$ to $54 \%$. The percentage of jobs requiring or preferring longer work experience (e.g., "three years or more," "five years or more") has decreased. The fact that more entry-level positions were available over the years shows an increasing demand in both areas.

In tables $6 \mathrm{~A}, 6 \mathrm{C}$, and $6 \mathrm{D}$ we find that there are no significant differences between catalog and reference librarians in work experience during the first, third, and fourth periods. The frequency distributions indicate, however, that positions for catalog librarians were more likely to require or prefer previous work experience. Reser and Schuneman (1992) explained that the complex rules involved in cataloging require that more time be spent training a cataloger than training a beginning reference librarian. It is economic and effective to seek catalogers with solid work experience. In the second period under study, the reference positions were more likely than the cataloging positions to require five years or more of experience, and the differences are significant at the $\mathrm{p}$ level (table $6 \mathrm{~B}$ ). This is probably due to the fact that more of the reference librarian positions in the second period involved administrative responsibilities.

\section{Computer Skills}

As automation is becoming more pervasive in library services, the degree to which institutions advertise for librarians 
TABLE 6A

WORK EXPERIENCE REQUIRED DURING 1971-75

\begin{tabular}{|c|c|c|c|c|c|c|c|c|c|c|c|c|}
\hline \multirow[b]{2}{*}{ Type } & \multicolumn{2}{|c|}{$\begin{array}{l}\text { Not Stated } \\
\text { or Prefer }\end{array}$} & \multicolumn{2}{|c|}{ Required } & \multicolumn{2}{|c|}{$\begin{array}{l}1 \text { Year } \\
\text { or More }\end{array}$} & \multicolumn{2}{|c|}{$\begin{array}{l}3 \text { Years } \\
\text { or More }\end{array}$} & \multicolumn{2}{|c|}{$\begin{array}{l}5 \text { Years } \\
\text { or More }\end{array}$} & \multicolumn{2}{|c|}{ Total } \\
\hline & No. & $\%$ & No. & $\%$ & No. & $\%$ & No. & $\%$ & No. & $\%$ & No. & $\%$ \\
\hline Cat librarians & 7 & 31.82 & 6 & 27.27 & 2 & 9.09 & 4 & 18.18 & 3 & 13.63 & 22 & 51.16 \\
\hline Ref. librarians & 10 & 47.62 & 4 & 19.05 & 2 & 9.52 & 3 & 14.29 & 2 & 9.52 & 21 & 48.84 \\
\hline Total & 17 & 39.53 & 10 & 23.26 & 4 & 9.30 & 7 & 16.28 & 5 & 11.63 & 43 & 100.00 \\
\hline
\end{tabular}

$X^{2}=1.250, d f=4, p=0.870$

TABLE 6B

WORK EXPERIENCE REQUIRED DURING 1976-80

\begin{tabular}{|c|c|c|c|c|c|c|c|c|c|c|c|c|}
\hline \multirow[b]{2}{*}{ Type } & \multicolumn{2}{|c|}{$\begin{array}{l}\text { Not Stated or } \\
\text { Prefer }\end{array}$} & \multicolumn{2}{|c|}{ Required } & \multicolumn{2}{|c|}{$\begin{array}{l}1 \text { Year } \\
\text { or More }\end{array}$} & \multicolumn{2}{|c|}{$\begin{array}{l}3 \text { Years } \\
\text { or More }\end{array}$} & \multicolumn{2}{|c|}{$\begin{array}{l}5 \text { Years } \\
\text { or More }\end{array}$} & \multicolumn{2}{|c|}{ Total } \\
\hline & No. & $\%$ & No. & $\%$ & No. & $\%$ & No. & $\%$ & No. & $\%$ & No. & $\%$ \\
\hline $\begin{array}{l}\text { Cat. } \\
\text { librarians }\end{array}$ & 16 & 37.21 & 8 & 18.60 & 10 & 23.26 & 7 & 16.28 & 2 & 4.65 & 43 & 40,19 \\
\hline $\begin{array}{l}\text { Ref. } \\
\text { librarians }\end{array}$ & 31 & 48.44 & 4 & 6.25 & 6 & 9.38 & 13 & 20.31 & 10 & 15.63 & 64 & 59.81 \\
\hline Total & 47 & 49.93 & 12 & 11.21 & 16 & 14.95 & 20 & 18.69 & 12 & 11.21 & 107 & 100,00 \\
\hline
\end{tabular}

$X^{2}=10.538, d f=4, p=0,032$

TABLE 6C

WORK EXPERIENCE REQUIRED DURING 1981-85

\begin{tabular}{|c|c|c|c|c|c|c|c|c|c|c|c|c|}
\hline \multirow[b]{2}{*}{ Type } & \multicolumn{2}{|c|}{$\begin{array}{l}\text { Not Stated } \\
\text { or Prefer }\end{array}$} & \multicolumn{2}{|c|}{ Required } & \multicolumn{2}{|c|}{$\begin{array}{l}1 \text { Year } \\
\text { or More }\end{array}$} & \multicolumn{2}{|c|}{$\begin{array}{l}3 \text { Years } \\
\text { or More }\end{array}$} & \multicolumn{2}{|c|}{$\begin{array}{l}5 \text { Years } \\
\text { or More }\end{array}$} & \multicolumn{2}{|c|}{ Total } \\
\hline & No. & $\%$ & No. & $\%$ & No. & $\%$ & No. & $\%$ & No. & $\%$ & No. & $\%$ \\
\hline Cat. librarians & 38 & 49.35 & 6 & 7.79 & 14 & 18.18 & 12 & 15.58 & 7 & 9.09 & 77 & 51.68 \\
\hline Ref. librarians & 39 & 54.17 & 4 & 5.56 & 13 & 18.06 & 12 & 16.67 & 4 & 5.56 & 72 & 48.32 \\
\hline Total & 77 & 51.68 & 10 & 6.71 & 27 & 18.12 & 24 & 16.11 & 11 & 7.38 & 149 & 100.00 \\
\hline
\end{tabular}

$X^{2}=1.102, d f=4, p=0.894$

with computer knowledge and skills is an important concern. Does the rapid expansion of computer applications in libraries coincide with the required computer knowledge for a particular job?

In this study, "computer skills" was defined broadly to include knowledge of or experience with any of a wide variety of computer applications, including bibliographic utilities, online database searching, CD-ROM, and other end user searching cases. There is no evidence from the data that catalog and reference librarians require the same computer skills. Adver- tisements for catalogers always ask for knowledge about OCLC, RLIN, or other bibliographic utilities, while those for reference librarians mainly require experience in searching DIALOG, BRS, or other online services. A job listing might include more than one computer skill for a particular position. No cross-tabulations were made for between-group and within-group analyses.

Computer skills for catalog librarians were divided into the following groups: computer applications, automated cataloging, OCLC, RLIN, and other biblio- 
TABLE 6D

WORK EXPERIENCE REQUIRED DURING 1986-90

\begin{tabular}{|c|c|c|c|c|c|c|c|c|c|c|c|c|}
\hline \multirow[b]{2}{*}{ Type } & \multicolumn{2}{|c|}{$\begin{array}{l}\text { Not Stated } \\
\text { or Prefer }\end{array}$} & \multicolumn{2}{|c|}{ Required } & \multicolumn{2}{|c|}{$\begin{array}{l}1 \text { Year } \\
\text { or More }\end{array}$} & \multicolumn{2}{|c|}{$\begin{array}{l}3 \text { Years } \\
\text { or More }\end{array}$} & \multicolumn{2}{|c|}{$\begin{array}{l}5 \text { Years } \\
\text { or More }\end{array}$} & \multicolumn{2}{|c|}{ Total } \\
\hline & No. & $\%$ & No. & $\%$ & No. & $\%$ & No. & $\%$ & No. & $\%$ & No. & $\%$ \\
\hline Cat. librarians & 62 & 51.67 & 12 & 10.00 & 29 & 24.17 & 11 & 9.17 & 6 & 5.00 & 120 & 43.67 \\
\hline Ref. librarians & 84 & 54.19 & 15 & 9.68 & 32 & 20.65 & 16 & 10.32 & 8 & 5.16 & 155 & 56.36 \\
\hline Total & 146 & 53.09 & 27 & 9.82 & 61 & 22.18 & 27 & 9.82 & 14 & 5.09 & 275 & 100,00 \\
\hline
\end{tabular}

$X^{2}=0.562, d f=4, p=0.967$

graphic utilities (computer online searching was included although only one listing in 1980 and one listing in 1986 mentioned it). Computer skills for reference librarians were divided into these groups: computer applications, online database searching in general, DIALOG, BRS, other specific online database searching, CD-ROM searching, OCLC, and RLIN.

Since the 1970s, probably the single most significant impact in the area of academic library automation has been the emergence of OCLC and other online bibliographic utilities. Matthews (1980) reflects that only the OCLC utility existed in 1973, at which time it supported only about 80 terminals. By April 1979, approximately $28 \%$ of the academic libraries in the United States and Canada had access to a utility: OCLC (26\%), RLIN $(0.2 \%)$, UTLAS $(1 \%)$, or WLN $(0.4 \%)$. By 1985, OCLC had grown to cover 6,584 academic libraries (Bourdon 1986). The speed with which libraries have adopted online bibliographic services has been impressive. From table 1 one can see that only one advertisement for catalogers mentioned knowledge of computer applications in 1975. Many more advertisements requiring OCLC experience for catalog librarians and computer online database searching skills for reference librarians have occurred since 1977. Because the impact of automation in recruiting did not take effect until the mid-1970s, the analysis focused on the later three periods.

In figure 3 we find that knowledge of OCLC is most required or preferred for cataloging positions. It accounts for over half of automation systems or computer skills listed in each of the last three periods; although, with the innovations and adoption of other bibliographic utilities, the percentage has decreased after the third period (from about $65 \%$ to $58 \%$ ). RLIN experience was not asked for until 1981 (table 1). Adoption of other bibliographic utilities in the fourth period led to the increased requirement for knowledge of these. Experience in "automated cataloging" was first asked for in the second period (about $11 \%$ ), rose to $18 \%$ in the third period, and since then has declined as the need for specific skills related to bibliographic utilities has gone up.

For reference librarians, experience of computer database searching has been the most important component of job qualifications since 1980 (table 2). A survey of online searching in U.S. colleges and universities conducted by McKinney and Mosby (1986) shows that $41.8 \%$ of academic libraries offered in-house searching in 1984. In ten years, the percentage approximately doubled. The survey also showed that the leading vendor for academic libraries was DIALOG (in $87 \%$ of the libraries). The other leading vendors were BRS (50\%) and SDC (15\%). DIALOG and BRS were the two services most widely adopted (see figure 4) in academic libraries during the third period (over $30 \%$ of advertisements asked for knowledge of DIALOG or BRS). "Online database searching" experience (service unspecified) applied to $36 \%$ of the advertisements in the second period, $43 \%$ in the third period, and $47 \%$ in the fourth period. A huge increase in the availability of databases, especially on CD-ROM, in aca- 


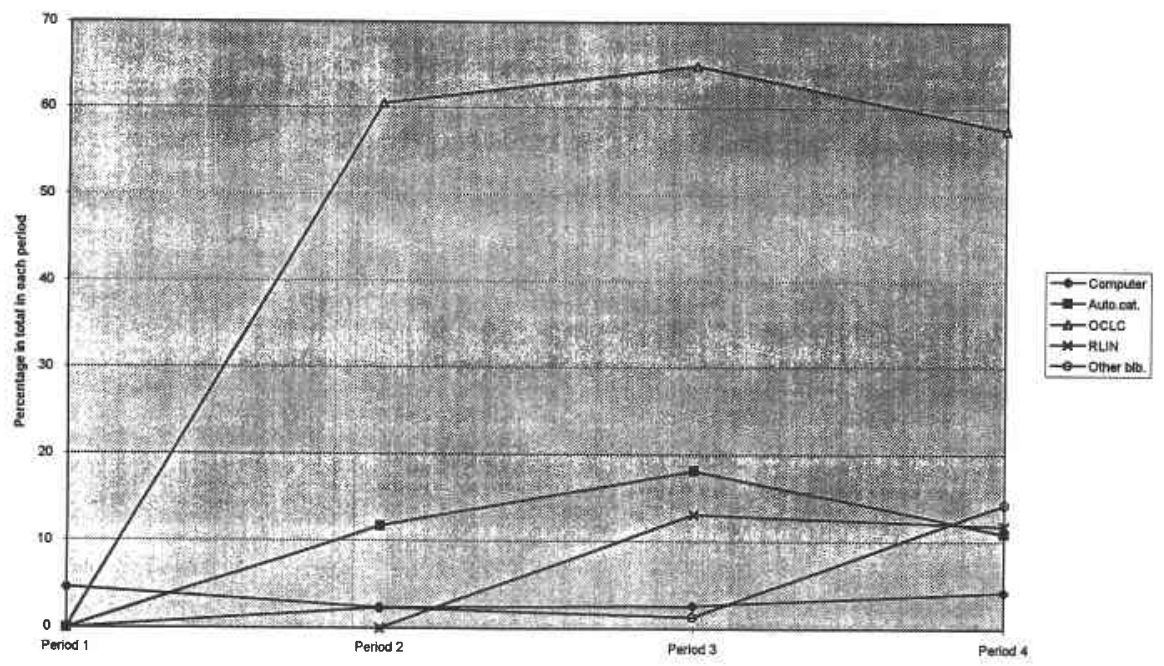

Figure 3. Computer skills required for catalog librarians

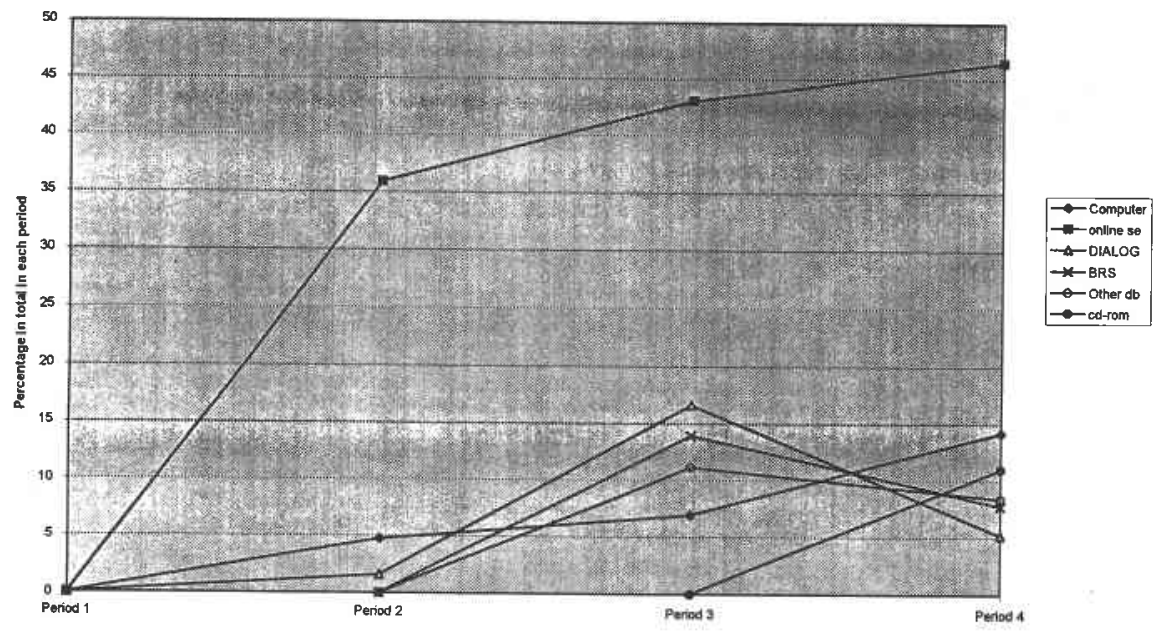

Figure 4. Computer skills required for reference lil)rarians

demic libraries during the third period brought about increasing need for skills and knowledge about these databases. The need for CD-ROM experience has increased over the years since 1986 (table 2). General knowledge about computer applications has been given much more attention in the period 1986-1990. Since 1986, also, reference duties have expanded to include familiarity with sources formerly associated with technical services. For example, several positions have asked for OCLC and RLIN experience (table 2). 
According to a survey by ARL, over I,500 commercially available CD-ROM products have been introduced to offer patrons the opportunity to obtain information through inexpensive, user-friendly formats since the mid-1980s (Clark 1990). CD-ROM products and databases have become an integral part of research library services and operations. The availability of CD-ROM databases has created a large demand for instruction and demonstration of the searching capabilities of this new technology. Knowledge and skill in using CD-ROM has therefore become essential for reference librarians. However, the job advertisements do not fully reflect this practical requirement. Not until 1987 was CD-ROM experience mentioned. During the period 1986-1990 only 17 of 155 advertisements required CDROM experience (table 2). Probably most CD-ROM training (classes, workshops, and seminars) was on-the-job training provided by libraries themselves. Clark (1990) has predicted that demands for instruction, publicity, and technical expertise relating to $\mathrm{CD}-\mathrm{ROM}$ are likely to continue to grow.

\section{ADMINISTRATIVE RESPONSIBILITIES AND OTHER SKILLS}

Job titles that include the term "head," "director," "assistant or associate head or director," or "coordinator," and job duties that include the term "supervision," "management," or "coordination" were considered as positions that have administrative responsibilities.

Chi-square tests were performed to see whether there were any differences among the periods for cataloging or reference services, and whether catalogers tended to have more management responsibilities than reference librarians with the development of library automation.

In both categories, although the absolute number of jobs requiring supervising, administrative, or coordinating responsibilities increased from period to period, as percentages of total jobs, the management requirements have actually decreased. A job listing that had both supervisory or administrative and coordinating duties was counted once in the "supervision or administration" group. Statistically significant differences were not found for either type over the four periods (tables 7A-7B). From tables 1 and 2 one can see that coordinating did not become one of the job duties throughout the periods studied, ranging from 0 to $11 \%$.

Chi-square tests show that during the first two periods there were no significant differences between catalog and reference librarians with regard to administrative responsibilities (see tables $8 \mathrm{~A}-8 \mathrm{~B}$ ); from the third period, statistically significant differences (at $p$ level) were found (see tables 8C-8D). Obviously, catalog librarians tend to have more administrative responsibilities than reference librarians. During the period 1981 to 1985 , catalog librarian postings with supervisory or administrative (44\%) and coordinating responsibilities ( $8 \%$ ) accounted for $52 \%$ of the total of 77 advertisements; whereas reference postings with supervisory or administrative (17\%) and coordinating (8\%) responsibilities only accounted for about $25 \%$ of the total of 72 advertisements. In the fourth period, catalog postings with administrative responsibilities decreased slightly to $47 \%$ of the total of 120 , and reference postings decreased to $20 \%$ of the total of 155 . This might be consistent with the views that catalogers tend to have more managerial responsibilities than reference librarians with the development of library automation.

Distinguishing titles with managerial responsibilities from nonadministrative catalog or reference librarian postings, the conclusion that catalogers tend to have more administrative responsibilities than reference librarians can be more strongly supported. Since the first period (tables 1 and 2) the percentage of the advertisements for nonadministrative catalogers requiring supervisory or administrative duties has increased from about $8 \%$ to $37 \%$. On the other hand, less than $13 \%$ of the advertisements for nonadministrative reference librarians required supervisory or administrative duties, except in the second period, where the figure was $26 \%$. The fourth period decreased to the lowest, about $9 \%$. 
TABLE 7A

Administrative Responsibilities For Catalog LibraRians over Four PeRiods

\begin{tabular}{lrrrrrrrrrr}
\hline & \multicolumn{2}{c}{$1971-75$} & \multicolumn{2}{c}{$1976-80$} & \multicolumn{2}{c}{$1981-85$} & \multicolumn{2}{c}{$1986-90$} & \multicolumn{2}{c}{ Total } \\
Responsibilities & \multicolumn{1}{c}{ No. } & \multicolumn{1}{c}{$\%$} & \multicolumn{1}{c}{ No. } & \multicolumn{1}{c}{$\%$} & \multicolumn{1}{c}{ No. } & \multicolumn{1}{c}{$\%$} & \multicolumn{1}{c}{ No. } & \multicolumn{1}{c}{$\%$} & \multicolumn{1}{c}{ No. } & \multicolumn{1}{c}{$\%$} \\
\hline Super/adminis. & 11 & 50.00 & 12 & 27.91 & 34 & 44.16 & 48 & 40.00 & 105 & 40.08 \\
Coordination & 0 & 0.00 & 4 & 9.30 & 6 & 7.79 & 8 & 6.67 & 18 & 6.87 \\
Not mentioned & 11 & 50.00 & 27 & 62.79 & 37 & 48.05 & 64 & 53.33 & 139 & 53.05 \\
Total & 22 & 8.40 & 4.3 & 16.41 & 77 & 29.39 & 120 & 45.80 & 262 & 100.00 \\
\hline
\end{tabular}

$X^{2}=5.606, d f=6, p=0.469$

TABLE 7B

Administrative Responsibilities for Reference Librarians over Four Periods

\begin{tabular}{lrrrrrrrrrrr}
\hline & \multicolumn{2}{c}{$1971-75$} & \multicolumn{2}{c}{$1976-80$} & \multicolumn{2}{c}{$1981-85$} & \multicolumn{2}{c}{$1986-90$} & \multicolumn{2}{c}{ Total } \\
Responsibilities & \multicolumn{1}{c}{ No } & \multicolumn{1}{c}{$\%$} & \multicolumn{1}{c}{ No } & \multicolumn{1}{c}{$\%$} & \multicolumn{1}{c}{ No. } & \multicolumn{1}{c}{$\%$} & \multicolumn{1}{c}{ No. } & \multicolumn{1}{c}{$\%$} & No. & \multicolumn{1}{c}{$\%$} \\
\hline Super/adminis. & 7 & 33.33 & 18 & 28.13 & 12 & 16.67 & 24 & 15.48 & 61 & 19.55 \\
Coordination & 1 & 4.76 & 7 & 10.94 & 6 & 8.33 & 7 & 4.52 & 21 & 6.73 \\
Not mentioned & 13 & 61.90 & 39 & 60.94 & 54 & 75.00 & 124 & 80.00 & 230 & 73.72 \\
Total & 21 & 6.73 & 64 & 20.51 & 72 & 23.08 & 155 & 49.68 & 312 & 100.00 \\
\hline
\end{tabular}

$X^{2}=1.1 .934, d f=6, p=0.063$

Communication ability, which includes both oral and written skills, is important in management and coordination activities. Communication skills were first mentioned in the second period (tables 1 and 2) for both categories. Since then, the proportion that listed the skills increased to one-fourth for catalog librarians and one-third for reference librarians.

\section{HOLISTIC LIBRARIANS}

One view on the future of librarianship is that librarians will become increasingly "holistic." This can be tested by tracking the percentage of catalog postings that include noncataloging duties such as reference, bibliographic instruction, collection development, circulation, and interlibrary loan, and by tracking the percentage of reference postings requiring nonreference duties such as cataloging, collection development, circulation, interlibrary loan, and bibliographic instruction. The data indicate that there are still few catalogers involved in noncataloging duties, although reference duties were included in a cataloger position as early as 1979 .

There is no evidence from the sample that catalog librarians were required to have bibliographic instruction, collection development, circulation, and interlibrary loan duties. The major qualification for catalog librarians has been special knowledge of AACR2, LCSH, Library of Congress Classification (LCC), Dewey Decimal Classification (DDC), or the Machine-Readable Cataloging (MARC) format since 1976 (see table 1 and figure 5). One might conclude that overwhelming numbers of positions for catalog librarians asked for knowledge of LCC rather than $D D C$; with the implementation of online bibliographic systems, the development of cooperative cataloging, $A A C R 2$ as cataloging rules, and the MARC format as the standard for coding data for all of bibliographic systems, there is an increasing need for knowledge of $L C S H, A A C R 2$, and the MARC format.

Cataloging and other technical services are still not part of the reference 


\section{TABLE 8A}

ADMINISTRATIVE RESPONSIBILITIES DURING 1971-75

\begin{tabular}{lrccccccc}
\hline \hline & \multicolumn{2}{c}{ Super/Adminis. } & \multicolumn{2}{c}{ Coordination } & \multicolumn{2}{c}{ Not Mentioned } & \multicolumn{2}{c}{ Total } \\
Type & \multicolumn{1}{c}{ No. } & $\%$ & No & $\%$ & No. & $\%$ & No. & $\%$ \\
\hline Catalog librarians & 11 & 50.00 & 0 & 0.00 & 11 & 50.00 & 22 & 51.16 \\
Reference librarians & 7 & 33.33 & 1 & 4.76 & 13 & 61.90 & 21 & 48.84 \\
Total & 18 & 41.86 & 1 & 2.33 & 24 & 55.81 & 43 & 100.00 \\
\hline
\end{tabular}

$X^{2}=2.033, d f=2, p=0.362$

TABLE 8B

Administrative Responsibilities duRING 1976-80

\begin{tabular}{lcccccccc}
\hline & \multicolumn{2}{c}{ Super/Aáminis } & \multicolumn{2}{c}{ Coordination } & \multicolumn{2}{c}{ Not Mentioned } & \multicolumn{2}{c}{ Total } \\
Type & No. & $\%$ & No. & $\%$ & No. & $\%$ & No. & $\%$ \\
\hline Catalog librarians & 12 & 27.91 & 4 & 9.30 & 27 & 40.91 & 43 & 40.19 \\
Reference librarians & 18 & 28.13 & 7 & 10.94 & 39 & 59.09 & 64 & 59.81 \\
Total & 30 & 28.04 & 11 & 10.28 & 66 & 61.68 & 107 & 100.00 \\
\hline
\end{tabular}

$X^{2}=0.082, d f=2, p=0.960$

TABLE 8C

ADMINISTRATIVE RESPONSIBILITIES DURING 1981-85

\begin{tabular}{lccrccccc}
\hline & \multicolumn{2}{c}{ Super/Adminis } & \multicolumn{2}{c}{ Coordination } & \multicolumn{2}{c}{ Not Mentioned } & \multicolumn{2}{c}{ Total } \\
Type & No. & $\%$ & No & $\%$ & No. & $\%$ & No & $\%$ \\
\hline Citalog librarians & 34 & 44.16 & 6 & 7.79 & 37 & 48.05 & 77 & 51.68 \\
Reference librarians & 12 & 16.67 & 6 & 8.33 & 54 & 75.00 & 72 & 48.32 \\
Total & 46 & 30.87 & 12 & 8.05 & 91 & 61.07 & 149 & 100.00 \\
\hline
\end{tabular}

$X^{2}=13.545, d f=2, p=0.001$

\section{TABLE 8D}

\section{ADMINISTRATIVE RESPONSIBILITIES DURING 1986-90}

\begin{tabular}{lcccccccc}
\hline & \multicolumn{2}{c}{ Super.Adminis. } & \multicolumn{2}{c}{ Coordination } & \multicolumn{2}{c}{ Not Mentioned } & \multicolumn{2}{c}{ Total } \\
Type & No. & $\%$ & No. & $\%$ & No. & $\%$ & No. & $\%$ \\
\hline Catalog librarians & 48 & 40.00 & 8 & 6.67 & 64 & 53.33 & 120 & 43.64 \\
Reference librarians & 24 & 15.48 & 7 & 4.52 & 124 & 80.00 & 155 & 56.36 \\
Total & 72 & 26.18 & 15 & 5.45 & 188 & 68.36 & 275 & 100.00 \\
\hline
\end{tabular}

$X^{2}=23.136, d f=2, p=0.000$

librarian's job duties. Knowledge of classification, subject headings, or the MARC format was not mentioned in any advertisement for reference librarians, although a few listings have asked for OCLC or RLIN experience since 1986 (see table 2). This suggests that few changes have occurred with regard to integrating the roles of public and technical services librarians since Busch's survey in 1985. That is, the use of technical services personnel for online searching of refer- 


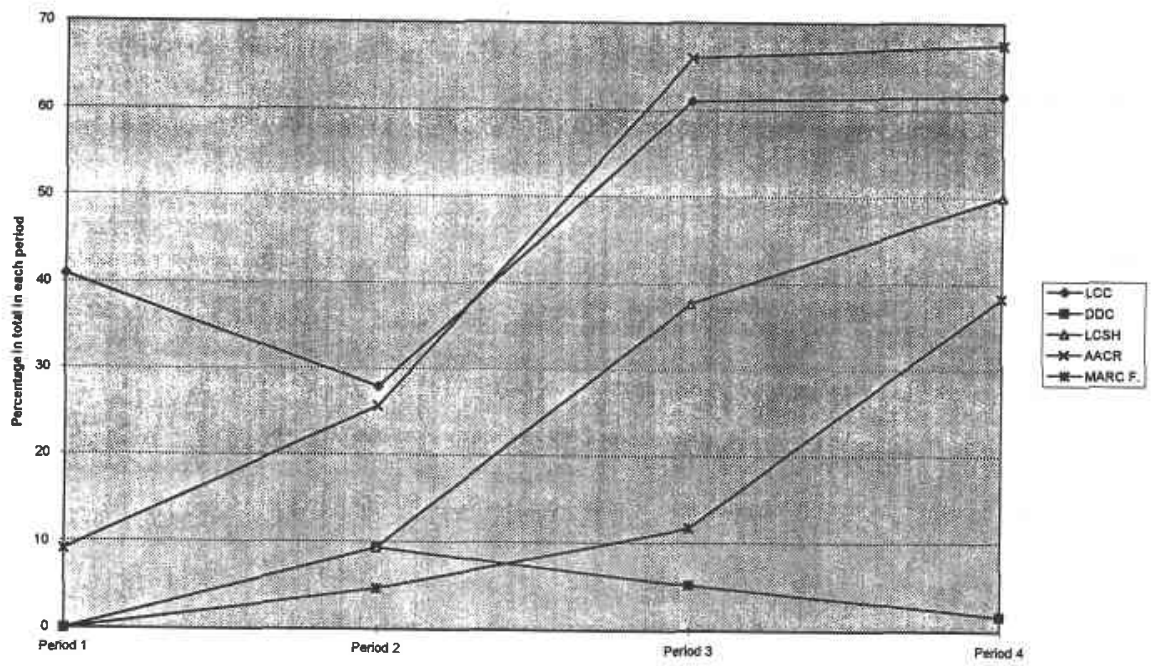

Figure 5. Special knowledge needed by catalog librarians

ence databases is still relatively rare and public service staff are even less likely to be involved in cataloging (Busch 1985).

Bibliographic instruction (BI) was not a firmly entrenched element in academic libraries until 1975, when an ACRL task force provided guidelines for bibliographic instruction in academic libraries. They recognized that the primary role of bibliographic instruction is to provide students with the specific skills needed to successfully use the bibliographic structure housed in the library. Bibliographic instruction has been strongly influenced by changes in library technology. With the development of online catalogs, more and more of a reference librarian's time is likely to be spent providing instruction in the use of electronic sources (Crane 1990). The availability of end user searching (mainly CD-ROM database searching) might mean a further change in the focus of reference service. End user searching will increase greatly the demand and need for user instruction.

In table 2, we see that bibliographic instruction responsibility was specified in advertisements for reference librarians as early as 1978 . Since then, more and more have been expected to have bibliographic instruction duties. By 1990, over half of the reference positions specified bibliographic instruction duties (19 of 35 positions), although independent bibliographic instruction departments already existed in some academic libraries and many advertisements for "BI instructor," "BI coordinator," or "BI librarian" were seen.

Public services librarians, especially reference librarians who are in daily contact with library users, know the strengths and weaknesses of the collection best. They are in the best position to evaluate the collection in terms of user needs (Bone 1983). Checking table 2 and figure 6 , one might find a steadily increasing need for reference librarians to have collection development responsibilities. Figure 6 reflects the trend of increasing bibliographic instruction and collection development duties for reference librarians over the four periods.

Few reference librarians are involved in circulation or interlibrary loan duties because these services are more often performed by paraprofessionals and other support staff. This is primarily because these services have become more routine with the development of automation. 


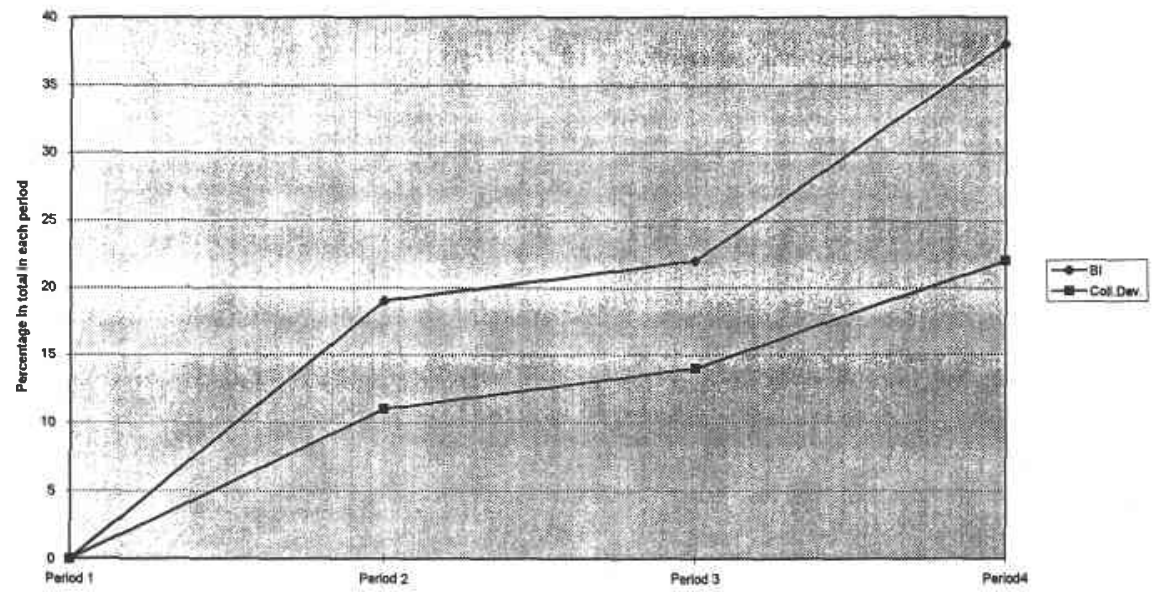

Figure 6. BI or collection development duties for reference librarians

\section{Conclusion}

Content analysis of job advertisements does indicate that, with the development of automation in libraries: the requirements of previous work experience for catalog and reference librarians are becoming more similar; increasing needs for computer skills can be found in both categories, although the skills requested are quite different; and the shortage of catalogers and the greater demand for reference librarians have led to more entrylevel positions being listed in both areas. However, the differences in major responsibilities and knowledge or skills needed reveal that the completely holistic librarian, as Gorman (1983) has described, might be some time in arriving. The theory of Ogburn's "cultural lag" is also well supported by the study.

Although the effect of automation on qualifications and responsibilities of cata$\log$ and reference librarians can be traced through the analysis of job advertisements, there are too many uncontrollable variables to support far-reaching conclusions. First, a brief job description cannot fully embody the complete requirements and responsibilities of a particular librar- ian. Second, there are differences in requirements between postings and the real applicants. Genaway (1978) demonstrated that a large number of job applicants in his sample did not fit the originally advertised requirement. A survey by the Cataloging and Classification Section (CCS) of ALCTS also reflects the gap between advertisements and the real world: in 94 positions advertised with cataloging components, the task force found that $51 \%$ reported a disappointing applicant pool; $37 \%$ interviewed more than four candidates, but no institution found more than three potentially appointable candidates in a pool. Third, once certain sorts of requirements or responsibilities have become relatively commonplace, they might not always be mentioned in job descriptions. For example, whereas some advertisements in the earlier period might have required knowledge of LCC for catalogers or skill in using different kinds of printed reference tools for reference librarians, during the later period such skills might have been ignored because familiarity with classifications or reference tools is now considered a "given" for a qualified cataloger or reference librarian. Moreover, the wording 
of advertisements often reflects compromises among members of the search committee. Finally, because the study was limited to catalogers and reference librarians, one cannot find evidence of technological impact on the whole organization and professional structure of academic libraries. For example, with the development of automation, other job titles such as "subject librarian," "systems librarian," or "access librarian" might multiply and reflect an increasing trend toward holistic librarians.

With the accelerating development of the computer network and its extensive application in academic libraries, impact on job requirements and qualifications for catalogers and reference librarians will be more tremendous and instantaneous. This is something that needs to be explored by further study.

\section{WORKS CITED}

Arret, Linda, 1979. New catalog/new librarian? Reference and LC. RQ 19: 44-51.

Atkinson, Hugh C. 1984. The impact of new technology on library organization. In The Bowker annual of library and book trade information, 20th ed., ed. J. Ehresmann. New York: R.R. Bowker, 109-14.

Bishoff, Liz. 1989. Recruiting, what next? In Recruiting, educating, and training cataloging librarians, ed. S. S. Intner and J. S. Hill. New York: Greenwood, 39-51.

Block, David. 1980. Emerging personnel requirements in academic libraries as reflected in recent position announcements. ERIC (ED 215703 ).

Bone, Larry E. 1983. Noblesse oblige: Collection development as a public service responsibility. The reference librarian, no. 9: 65-73.

Boss, Richard W. 1987. The future of technology in libraries. Paper presented, 9 Feb., at the School of Library and Information Science, Indiana University, Bloomington, Indiana.

Bourdon, Cathleen. 1986. Academic libraries. In ALA yearbook of library and information services 11: 29-36.

Busch, B. J. 1985. Automation and the integration of public and technical service functions. RTSD newsletter 10, no. 3: 25-26.

Callahan, Daren, and Judy MacLeod, 1994. Recruiting and retention revisited: A study of entry level catalogers. Technical services quarterly 11, no. 4:27-43.
Cataloging and Classification Section, Association for Library Collections and Technical Services 1986. CCS task force on education and recruitment for cataloging report (June). RTSD newsletter 11, no. 7 : $71-78$.

Clark, Barton M., and Karen H. Bingham. 1989. Holistic librarianship: As it works. In Building on the first century, proceedings of the fifth national conference of the Association of College and Research Libraries, Cincinnati, Ohio, April 5-8, 1989, ed. J. C. Fennell and others. Chicago: ACRL, 5154.

Clark, Katie. 1990. Management of CD-ROM databases, SPEC Kits No. 169, Nov./Dec.

Cochrane, Pauline A. 1983. The changing roles and relationships of staff in technical services and reference/readers' services in the era of online public access catalogs. The reference librarian, no. 9: 45-54,

Cooper, Michael D. 1984. Projections of the demand for librarians in the United States. Library quarterly 54: 331-67.

Crane, Nancy B. 1990. Academic reference service in transition. In Library technology 1970-1990: Shaping the library of the future: Research contributions from the 1990 Computers in Libraries Conference, ed, N. M. Nelson. Westport, Conn.: Meckler, 1534.

Eaton, Nancy L. 1989. The electronic environment of the 1990s. In Recruiting, educating, and training cataloging librarians, eds. S. S. Intner and J. S. Hill. New York: Greenwood, 329-39.

Faries, Cindy. 1994. Reference librarians in the information age: Learning from the past to control the future. The reference librarian no. 43: 9-28.

Furuta, Kenneth. 1990. The impact of automation on professional catalogers. Information technology and libraries 9: 242-52.

Futas, Elizabeth. 1988. Current issues in reference and adult services. $R Q$ 28: 141-45.

Genaway, David C. 1978. Bar coding and the librarian supermarket: An analysis of advertised library vacancies. Library journal 103: 323-24.

Gorman, Michael, 1983. Online access and organization and administration of libraries. In Online catalogs, online reference converging trends: Proceedings of a $\mathrm{Li}$ brary and Information Technology Association preconference institute, June 2324, 1983, Los Angeles. Chicago: AACR, 153-64.

Hallman, Clark. N. 1990. Technology: Trigger for change in reference librarianship. The 
journal of academic librarianship 16: 2048.

Hewitt, Joe A. 1976. The impact of OCLC. American libraries 7: 268-75.

Hill, Janet S. 1985. Wanted: Good catalogers. American libraries 16: 728-30.

Hill, Janet S. 1988. Staffing technical services in 1995. Journal of library administration 9, no. 1: 87-103.

Hoerman, Heidi L. 1990. Short supply of catalogers. The ALA year book of library and information services: A review of library events. Vol. 15. Chicago: ALA, 90-91.

Huang, Samuel T. 1990. The impact of new library technology on reference services. Illinois libraries 72: 600-603.

Intner, Sheila S. 1991. Education for the dual role responsibilities of an access services librarian. The reference librarian no. 33: 107-26.

Lewis, David W. 1994. Making academic reference services work, College \& research libraries 55: 445-56.

Mandel, Carol A. 1992. Cooperative cataloging: Models, issues, prospects. In $A d-$ vances in librarianship. Ed. I. P. Godden. Vol. 16. San Diego; Academic, 33-82.

Matthews, Joseph R. 1980. Understanding the utilities: An introduction to the birth and development of the major online bibliographic utilities. American libraries 11:262, 264.

McCombs, Gillian. 1986. Public and technical services: Disappearing barriers. Wilson library bulletin 61, no. 3: 25-28.

McKinney, Gayle, and Anne P. Mosby. 1986. Online in academia: A survey of online searching in U.S. colleges and universities. Online review 10: 107-24.

Miller, Zana K. 1931. The catalog as a reference tool. Illinois libraries 13: 165-70.

Morrison, Margaret. 1990. The promise of new technology. In The Bowker annual: Library and book trade almanac, 34th. ed. (1989-1990), 79.

Neal, James G. 1989. The evolving public/technical services relationship: New opportunities for staffing the cataloging function. In Recruiting, educating, and training cataloging librarians, ed. S. S. Intner and J. S. Hill. New York: Greenwood, 111-19.

Nofsinger, Mary M., and Allan W. Bosch. 1994. Roles of the head of reference: From the 1990 s to the 21 st century. The reference librarian no. 43: 87-115.

Ogburn, William F. 1922. Social change with respect to culture and original nature. New York: B.W. Huebsch, Inc.

Reese, Jean. 1990. CD-ROM technology in libraries: Implications and considerations (using Vanderbilt University as an example). The electronic library 8, no. 1: 26-35.

Reser, David W., and Anita P. Schuneman. 1992. The academic library job market: A content analysis comparing public and technical services. College \& research libraries 53: 49-59.

Sanders, Thomas R. 1986. The cataloger crisis: Another view. American libraries 17: 310.

Scheaffer, Richard L, and others. 1986. Elementary survey sampling. 3d ed. Boston: Duxbury Press.

Shreeves, Edward. 1994. Embracing the inevitable. Journal of academic librarianship 20, no. 3: 136-37.

Spyers-Duran, Peter, 1979. The effects of automation on organizational change, staffing, and human relations in catalog departments. In Requiem for the card catalog: Management issues in automated cataloging, ed. Daniel Dore and others. Westport, Conn.: Greenwood, 29-39.

Summerhill, Craig A. 1994. The emerging national information infrastructure and reference services. The reference librarian, no. 43: 131-44.

Walbridge, Sharon L. 1991. New partnerships within the library. Joumal of library administration 15 , nos. 1/2: 61-72.

Williams, Delmus E. 1991. Managing technical services in the 1990s: The ruminations of a library director. Journal of library administration 15, nos. 1/2: 25-41. 